\title{
Participatory Variety Selection of Mung Bean (Vigna radiata (L.) Wilczek) at Sankura Wereda Silte Zone and Adamitulu Jido Kombolcha Wereda Eastern Shewa Zone of Ethiopia
}

\author{
*Wondimkun Dikr Dejene Tadesse \\ Ethiopian Institute of Agricultural Research, Wondo genet Agricultural Research Center \\ P. O Box, 198 Shashemene, Ethiopia
}

\begin{abstract}
This study was conducted in two selected potential areas of Ziway abine germama FTC in East Shewa Zone and Sankura wereda at Jejebicho research station Silte Zone of Ethiopia during 2019/2020 cropping season. The main objective of the study was to evaluate and select the best performing Mung bean varieties and to assess farmer's technology preference. The experiment was done using four released varieties namely; Rasa (N-26), NLV-1, Shewrobit and Arkebe varieties. The main objective of the study was to evaluate, select the best performing mung bean varieties and to assess farmer's technology preference. The experiment was done using four released varieties namely; Rasa (N-26), NLV-1, Shewrobit and Arkebe varieties. The analytical result showed that Rasa (N-26) variety was preferred by the farmers followed by Arkebe. The result gotten from the analysis of variance indicated that the difference among the means of the mung bean varieties for grain yield, number of pod per plant, number of seed per pod, days to physiological maturity and thousand seed weight were significant at 5\% probability level for Sankura district. But for Jido Kombolcha district days to physiological maturity, number of pod per plant, number of seed per pod, aboveground biomass, thousand seed weight, grain yield and harvest index were also significant at 5\% probability level. The highest Grain yield (18.01 Qt/ha) was recorded from Rasa (N-26) variety at Adamitulu Jido Kombolcha followed by the Arkebe variety (17.52 Qt/ha), while the lowest grain yield (13.01 Qt/ha) was obtained from the variety of Shewarobit at Adami tulu Jido Kombolcha district.The highest (24.00 Qt/ha) and lowest (12.48 Qt/ha) grain yield was obtained from variety Arkebe and NVL respectively. The grain yield of Rassa and Arkebe were significantly at par. The preference was first Rassa then second selected while in field variety evaluation. Therefore pre-scaling up of Arkebe and Rasa (N-26) variety with its improved management practice should be done.
\end{abstract}

Keywords: Arkebe, Baby trail, Grain yield, Mother trail and Rassa

DOI: $10.7176 / \mathrm{JBAH} / 11-3-04$

Publication date: February $28^{\text {th }} 2021$

\section{INTRODUCTION}

Mung bean is originated from India and it has diversified to East, South, Southeast Asia (China) and some countries in Africa. Mung bean (Vigna radiata (L.) Wilczek) is an important pulse crop in Asia because of its high protein content and ability to improve soil fertility (Asim et al., 2006). In Thailand, it is widely cultivated and occupied a cultivated area of 143,931 ha with the production of 102,799 ton of grain in 2009 (Thailand Office of Agricultural Economics, 2010). In Uganda, it is widely grown by smallholder farmers in the eastern and northern regions of the country (Ibedo, 2014). The genus Vigna has been broadened to embrace about 150 species; twenty two species are indigenous to India and sixteen to Southeast Asia, but the principal number of species are originate in Africa (Polhill and Maese, 1985). Mung bean a recent introduction in Ethiopian pulse production and grown in the north eastern part of Amhara region (North Shewa, Oromia special zone and Southern Wollo), SNNPR (Gofa area) and pocket areas in Oromiya region (Hararge). The average yield of the crop is limited to $600-800 \mathrm{~kg} / \mathrm{ha}$ due to different reasons (EPP, 2004). Ethiopia Commodity Exchange (ECX) announces the debut of a new commodity, green mung bean, into its trade floor. Green mung bean is the sixth product that Ethiopian Commodity Exchange is trading. Coffee, sesame, white pea, beans, maize and wheat have been traded in Ethiopian Commodity Exchange so far. Mung bean is mostly produced in Amhara regional state particularly in some areas of North Shewa and South Wollo as well as in some woreda's of Benishangul Gumuz regional state (ECX, 2014).

Ethiopia grows various types of pulse crops. Mung bean represents a vital component of agricultural food crops consumed in the country. The importance of growing the crop is associated to its high protein content and other essential minerals, especially micronutrients. Furthermore, this crop has the ability to fix atmospheric nitrogen (Delfin et al., 2008) and short duration maturity period which made it preferable crop for resource poor farmers in dry-land areas of the tropics and subtropics. Hayat et al. (2008) reported that $\mathrm{N}_{2}{ }^{-}$fixation under normal soil fertility condition by mung bean valued $47 \mathrm{~kg} \mathrm{ha}^{-1}$. Its seed contains $22.5 \%$ protein, $9.4 \%$ moisture, $2.05 \%$ fat, 6.95\% fiber and $343.5 \mathrm{kcal} / 100 \mathrm{~g}$ energy (Abas and Shah, 2007). In addition, the protein and carbohydrates of mung bean are more easily digestible than proteins derived from other legumes). Mung bean is 
an annual food legume belonging to the sub genus Ceratotropis in the genus Vigna. It is the seed of Phaseolus radiates $\mathrm{L}$. and an annual herb of the Leguminosae family. It has green skin and is also called green bean. It is sweet in flavor and cold in nature (EPP, 2004). Mung bean (Vigna radiata L.), a member of the Fabaceae family, is a tropical legume. It is a warm season annual, highly branched and having trifoliate leaves with plants varying from one to five feet in length (Khan et al., 2001). Intercropping is the practice of growing two or more crops together in a single field. Mung bean is also lower in phytic acid which is commonly found in cereal and other legume crops and has a negative impact on iron (Fe) and zinc (Zn) bio-availability (Nair et al., 2013). Despite holding such great promise in human nutrition and soil fertility improvement, the productivity of mung bean worldwide including in Ethiopia is quite low. This low yield is attributed to numerous factors including cultivation on marginal lands making it prone to a number of a biotic stresses, growing low yielding varieties and inappropriate agronomic practices. Use of good yielding varieties and applying the best agronomic practices are the best ways to increase yield of any crops.

Participatory Variety Selections (PVS) can thus effectively be used to identify farmer's acceptable varieties that are better than old and obsolete varieties with which farmers stick for long period (Joshi and Witcombe, 1996). Participatory varietal selections are farmer-centered varietal selections limited to testing of the finished varieties. Farmers evaluate multiple traits that are important to them and help to increase on farm varietal diversity, faster varietal replacement and rapid scaling up. Moreover, quality traits like milling percentage, cooking and keeping quality, taste, and market price can be assessed in PVS that are difficult or expensive to evaluate in conventional trials. All PVS use some form of mother and baby trials where the former are fewer in number than the latter has to compare all of the test entries (Witcoimbe et al., 2005). Similarly, participation of farmers during varietal selection in the selected areas is uncommon. This on-farm management and informal plant breeding increasingly becomes crucial in many areas of the developing world, while it ensures the conservation of genetic diversity and continuous evolution of crop species to meet local needs and environmental constraints (Smith et al., 2001). Although Ethiopia has high potential for increasing mung bean productivity and quality, little is known or unknown about the existing mung bean production, productivity and grain quality of the released varieties of mung bean through participatory variety selection to improve yield and quality and to develop alternative cultivars adaptable to the area. Therefore, it is of paramount importance to identify high yielding and good quality mung bean varieties for the area. Thus, this study was carried out to evaluate and select the best performing mung bean varieties and to assess farmer's technology references.

\section{MATERIALS AND METHODS}

\section{Description of the Study Area and Experimental Materials}

Participatory varietal selection of mung bean varieties was conducted Sankura woreda at Jejebicho research station in Silte Zone and Adamitul Jido Kombolcha woreda at Abine germama Kebele FTC in Eastern shewa Zone in 2019/20 main cropping season. At both locations these experiment was conducted at farmer's field and at FTC level for breeder data collection and for farmers' perceptions and decision. Mung bean: the selected released mung bean varieties 'Rasa (N-26), Arkebe, NVL-1 and Shewarobit' were used. It was released by Melkasa Agricultural Research Center and other regional research centers.

\section{Experimental Material and Design}

Four released mung bean varieties namely; Arkebe, Rasa (N-26), NVL-1, and Shewarobit were used and assessed on-farm and FTC level at both selected location. The experimental design was randomized complete block design with three replications at FTC and used non replication and simply randomized the treatments on four host farmer's field. The trail on FTC was used for breeder to collect data as mother trail. However on the other hand a trail on farm research named baby trial used for collect farmers' perceptions towards mung bean varieties selection. Four other host farmers planted one replication each as baby trial. The mother trial was used to generate breeder's data while the baby trials were also used for participatory varietal selection and to valued farmers' preferences during evaluation and variety selection.

\section{Data collection \\ Farmers' Data Collection}

Four different groups of farmers having eight members each were selected to rate different traits from emergence to maturity and post-harvest evaluation. Farmers and the breeder jointly evaluated the varieties, but the farmers alone made the final decision. Traits considered and criteria used for participatory varietal selection by farmers were: Plant stands (PS), Number of pods per plant (NPP), Number of seeds per pod (NSP), Disease Resistance (DR), Seed color (SC), Seed Size (SS), Marketability (Mrk.) and Earliness (Er).

\section{Breeders' Data Collection}

Plant height $(\mathrm{PH})$, branch number per plant $(\mathrm{BN})$, Days to $50 \%$ flowering (DFF \%), Days to physiological 
maturity (DPM), Number of pods per plant (NPP), Number of seed per pod (NSP), Above ground biomass (AGB), Thousand grain weight (TSW), Grain yield (GY and Harvest index (HI) were used.

\section{Statistical Data Analysis}

All data were subjected to the analysis of variance (ANOVA) appropriate to the randomized complete block design using SAS (Version, 9.4). Least significant difference (LSD) test at $5 \%$ level of probability was also used for mean separation as procedure described by Gomez and Gomez (1984). I used the linear model of RCBD while analyzed the data by SAS.

$\gamma \mathrm{ij}=\mu+\beta \mathrm{i}+\gamma \mathrm{i}+\varepsilon \mathrm{ij}$. where $\mu=$ common mean effect, $\beta \mathrm{i}=$ block effect, $\gamma \mathrm{i}=$ effects of varieties, $\varepsilon i j=$ experimental error

\section{RESULTS AND DISSCUSIONS}

Phenological, growth, yield and yield components of Mung bean varieties

The analysis of variance showed that days to physiological maturity of mung bean were significantly affected by varieties at both locations at Ziway and Sankura districts (Appendix Table 2).

The longest (93) and shortest (88.5) days to physiological maturity was taken at variety Arkebe and Shewarobit respectively (Table.1) at Adamitulu Jido Kombolcha district. However in Sankura district variety NVL takes the shortest time and variety Arkebe also takes the longest time, (84.5) and (93.6) days respectively to mature physiologically. This may due to the genotypic nature of varieties. Adamitulu Jido Kombolcha district Abine germama Kebele has a low rainfall and soil moisture stress area as compared to Sankura wereda Jejebicho research station. So variety NVL takes a very short time to mature and best for soil moisture stress environment.

The analysis of variance showed that plant height $(\mathrm{cm})$ of mung bean was significantly affected by varieties at Ziway districts, but non significance effect at Sankura district (Appendix Table 1). The analysis variance also showed that branch number was not significantly affected at both locations (Appendix Table 1\&2). The analysis variance also showed that, number of seed per pod, above ground biomass, thousand seed weight and grain yield were significantly affected by varieties at both locations, but Number of pod per plant was a significance effect on at Sankura district only. The highest (10.73) and lowest (8.65) number of seed per pod was recorded from variety of Rassa and NVL, respectively at Ziway district (Table 1). However the highest (13.85) number of seed per pod was recorded from Arkebe and lowest (10.45) number of seed per pod was recorded from NVL and Shewarobit at par at Sankura district (Table 2). The difference in number of seeds per pod might be because of inherent characteristics of the varieties. This result was agreed with experimental result of Jibril et al. (2015) showed that the genetic variation of mung bean varieties was created variations of its number of seed per pod. The analysis of variance showed that above ground biomass had a significance effect in between varieties of mung bean at Sankura district (Appendix table 1). The highest (27.10 Qt ha $\left.{ }^{-1}\right)$ and lowest (16.10 Qt ha $\left.{ }^{-1}\right)$ above ground biomass yield was recorded from variety of Arkebe and NVL at Sannkura district Jejebicho research station respectively (Table 2). Thousand seed weight was significantly affected by varieties of mung bean at both locations (Appendix Table 1 and 2) respectively. The highest (64g) and lowest (47g) thousand seed weight was recorded from Arkebe and NVL varieties at Ziway district respectively (Table 1). But the highest $(64.18 \mathrm{~g})$ and lowest $(41.44 \mathrm{~g}$ ) thousand seed weight was recorded from Rassa and NVL varieties respectively at Sankura district Jejebicho research station. Similarly agreed with the result of Mondal et al. (2012) reported the existence of significant difference in thousand seed weight among different cultivars of mung bean.

The analysis of variance showed that grain yield was significantly affected by varieties of mung at both locations (Appendix table 1 and 2). These experimental result supported by Yehuala et al. (2018) revealed that mung bean varieties had significant effect on grain yield. It is also supported by [Adhiena et al. 2015; Habte, 2018; Rasul et al. 2012; Teame et al. 2017 and Wedajo, 2015] The highest (18.01Qt ha' $\left.{ }^{-1}\right)$ and lowest (13.10Qt ha $^{-1}$ ) grain yield was measured from variety Rassa and Shewarobit respectively in Adamitulu Jido Kombolcha district at Abine Germama Kebele FTC (Table 1). The founding of (Fantaye et al., 2019) also agreed with this research result which revealed that grain yield of mung bean affected by varieties of it. However the highest $\left(24 \mathrm{Qt} \mathrm{ha} \mathrm{a}^{-1}\right)$ and lowest $\left(12.48 \mathrm{Qt} \mathrm{ha} \mathrm{h}^{-1}\right)$ grain yield was obtained from Arkebe and NVL varieties respectively, at Sankura Jejebicho research station. The highest harvest index was obtained from Arkebe (0.90), but the lowest harvest index was from NVL (0.78) from Jejebicho research station (Table 2). 
Table 1. Mean values of yield and yield components of mung bean varieties Adamitulu Jido Kombolcha district.

\begin{tabular}{llllllllll}
\hline Varieties & PH & BN & DPM & NPP & NSP & AGB & TSW & GY & HI \\
\hline Arkebe & $56.90 \mathrm{a}$ & 5.9 & $93.00 \mathrm{a}$ & 36.83 & $10.25 \mathrm{a}$ & 57.53 & $64.00 \mathrm{a}$ & $17.52 \mathrm{a}$ & 0.30 \\
Rassa & $45.33 \mathrm{~b}$ & 5.85 & $91.25 \mathrm{ab}$ & 35.48 & $10.73 \mathrm{a}$ & 47.22 & $63.25 \mathrm{a}$ & $18.01 \mathrm{a}$ & 0.38 \\
Shewarobit & $42.45 \mathrm{~b}$ & 5.83 & $88.50 \mathrm{~b}$ & 32.60 & $10.15 \mathrm{a}$ & 42.69 & $58.00 \mathrm{a}$ & $13.10 \mathrm{~b}$ & 0.31 \\
NVL & $40.53 \mathrm{~b}$ & 5.85 & $91.75 \mathrm{ab}$ & 31.90 & $8.65 \mathrm{~b}$ & 50.68 & $47.00 \mathrm{~b}$ & $13.88 \mathrm{~b}$ & 0.27 \\
\hline LSD & 7.89 & 0.8 & 3.36 & 9.85 & 0.71 & 24.13 & 9.23 & 1.71 & 0.21 \\
\hline CV $(\%)$ & 10.66 & 8.59 & 2.30 & 18.00 & 4.47 & 30.45 & 9.94 & 6.86 & 36.47 \\
\hline Significance level & $*$ & NS & $*$ & NS & $*$ & NS & $*$ & $*$ & NS \\
\hline
\end{tabular}

Where, $\mathrm{PH}=$ Plant height $(\mathrm{cm}), \mathrm{BN}=$ Branch number per plant, DPM=Days to physiological maturity, $\mathrm{NPP}=$ Number of pod per plant, $\mathrm{NSP}=$ Number of seed per plant, $\mathrm{AGB}=\mathrm{Above}$ ground biomass, $\mathrm{TSW}=$ Thousand seed weight (g), GY= Grain yield (Qunt/ha), HI=Harvest index an NS= non significance difference

Table 2. Mean values of yield and yield components of Mung bean varieties at Sankura district Jejebicho research station.

\begin{tabular}{llllllllll}
\hline Varieties & PH & BN & DPM & NPP & NSP & AGB & TSW & GY & HI \\
\hline Arkebe & 35.30 & 5.38 & $93.68 \mathrm{a}$ & $27.43 \mathrm{a}$ & $13.85 \mathrm{a}$ & $27.10 \mathrm{a}$ & $64.18 \mathrm{a}$ & $24.00 \mathrm{a}$ & $0.90 \mathrm{a}$ \\
Rassa & 34.75 & 6.03 & $92.68 \mathrm{a}$ & $24.73 \mathrm{a}$ & $13.18 \mathrm{a}$ & $23.90 \mathrm{a}$ & $63.83 \mathrm{a}$ & $20.24 \mathrm{a}$ & $0.85 \mathrm{ab}$ \\
Shewarobit & 33.58 & 5.63 & $87.25 \mathrm{~b}$ & $19.20 \mathrm{~b}$ & $10.45 \mathrm{~b}$ & $17.20 \mathrm{~b}$ & $54.09 \mathrm{ab}$ & $14.41 \mathrm{~b}$ & $0.84 \mathrm{ab}$ \\
NVL & 32.80 & 5.70 & $84.85 \mathrm{~b}$ & $18.90 \mathrm{~b}$ & $10.45 \mathrm{~b}$ & $16.10 \mathrm{~b}$ & $41.44 \mathrm{~b}$ & $12.48 \mathrm{~b}$ & $0.78 \mathrm{~b}$ \\
\hline LSD $(0.05)$ & 9.73 & 0.92 & 4.09 & 4.67 & 1.32 & 5.90 & 20.22 & 3.90 & 0.06 \\
\hline CV & 17.82 & 10.06 & 2.86 & 12.94 & 6.87 & 17.49 & 22.62 & 13.73 & 12.96 \\
\hline Significance level & NS & NS & $*$ & $*$ & $*$ & $*$ & $*$ & $*$ & $*$ \\
\hline
\end{tabular}

Farmer's preferences and scored values

The eight traits for evaluating the varieties of mung bean were discussed with the participants with description of plants in the field trials until each farmer clearly understood how to rate the varieties for each trait based on the scale. Farmers were also asked to indicate which varieties they would plant the following season. During the assessment, varieties were identified by plot numbers rather than by their names in order to avoid bias; as suggested by (Kapinga et al., 2003).

Farmers attended the participatory variety evaluation and had selection criteria to accept and reject mung bean variety (Table 3). The three different groups of farmers select varieties based on plant stand, number of pod per plant, number of seed per pod, diseases resistance, seed size, earliness, marketability and seed color of the variety. Arkebe was the most preferred variety by its plant stand, number of pod per plant and marketability. Rassa was the most preferred and preferred number of seed per pod and diseases resistance. Shewarobit was the most preferred by its maturity and earlier as compared to other three varieties. Based on the total score rating variety Arkebe is firstly and Rassa is secondly selected, but the remaining two i.e. Shewarobit and NVL were rejected by the participated farmers while in variety evaluation and selection (Table 3). Generally the common and most important selection criteria's in both locations that farmers identified were disease resistance, pod per plant, number of seed per pod, seed size for boldness and time of maturity (Table 3). As highlighted in Table 3 farmers were selecting Rasa (N-26) and Arkebe variety. On the other hand, NVL was not best adaptable to the area and hence farmers did not prefer it.

Table 3. Preference scoring of farmers for mung bean variety at the time of field evaluation

\begin{tabular}{|c|c|c|c|c|}
\hline \multirow[t]{2}{*}{ Criteria's of selection } & \multicolumn{3}{|c|}{ Varieties } & \multirow[b]{2}{*}{ NVL } \\
\hline & Arkebe & Rassa & Shewarobit & \\
\hline Plant stand & 4 & 3 & 2 & 1 \\
\hline Number of pod per plant & 4 & 3 & 2 & 1 \\
\hline Number of Seed per pod & 3 & 4 & 2 & 1 \\
\hline Diseases resistance & 3 & 4 & 1 & 2 \\
\hline Seed size & 3 & 3 & 3 & 3 \\
\hline Earliness & 1 & 2 & 4 & 3 \\
\hline Marketability & 4 & 3 & 3 & 2 \\
\hline Seed color & 4 & 3 & 3 & 1 \\
\hline Mean preference scored values & 3.25 & 3.13 & 2.5 & 1.75 \\
\hline Rank & 1 & 2 & 3 & 4 \\
\hline
\end{tabular}

Note, $1=$ least preferred $3=$ preferred $2=$ medium preferred and $4=$ most preferred 
Graph.1 showed that the highest grain yield of mung bean was obtained from Arkebe variety in Sankura district at Jejebicho research station except variety NVL. The other three varieties of mung bean gave better grain yield at Sankura Jejebicho research station. At Ziway the highest grain yield was obtained from variety Rassa and the lower yield was also from variety Shewarobit.

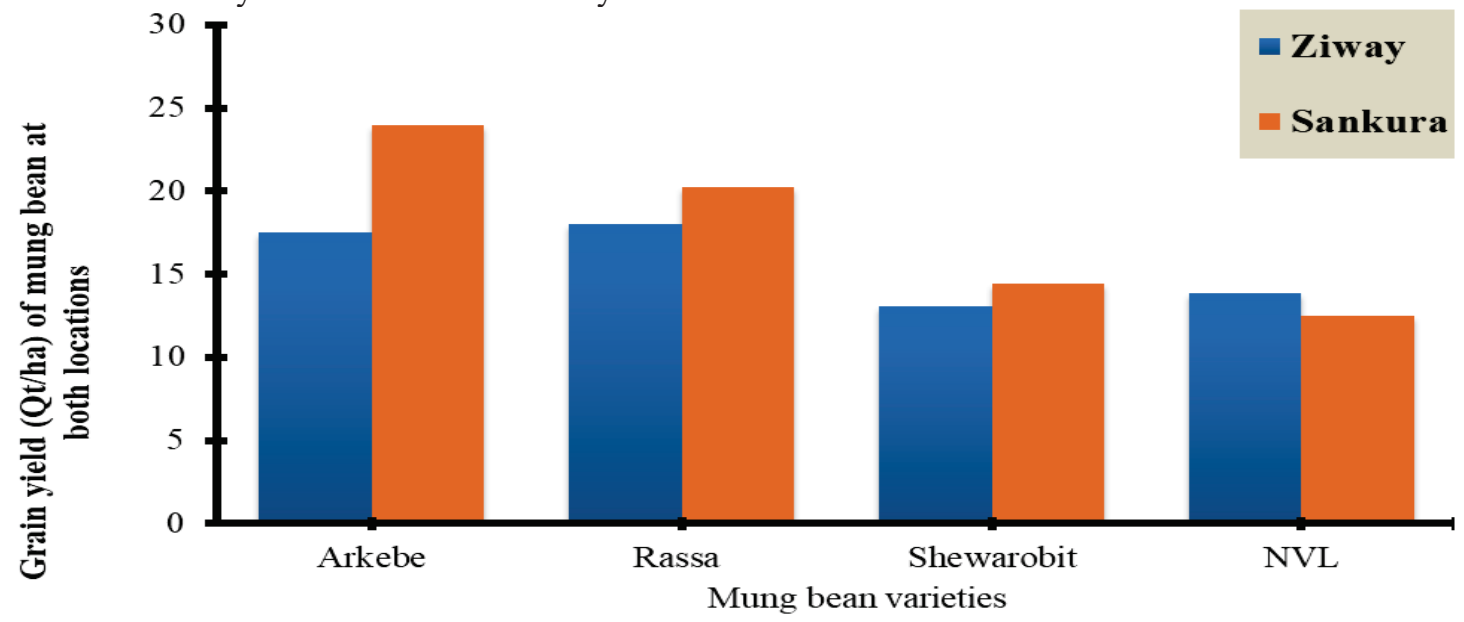

Graph 1. The Mean Grain yield (Qt/ha) of mung bean varieties at Adamitulu Jido Kombolcha (Ziway) and Sankura district.

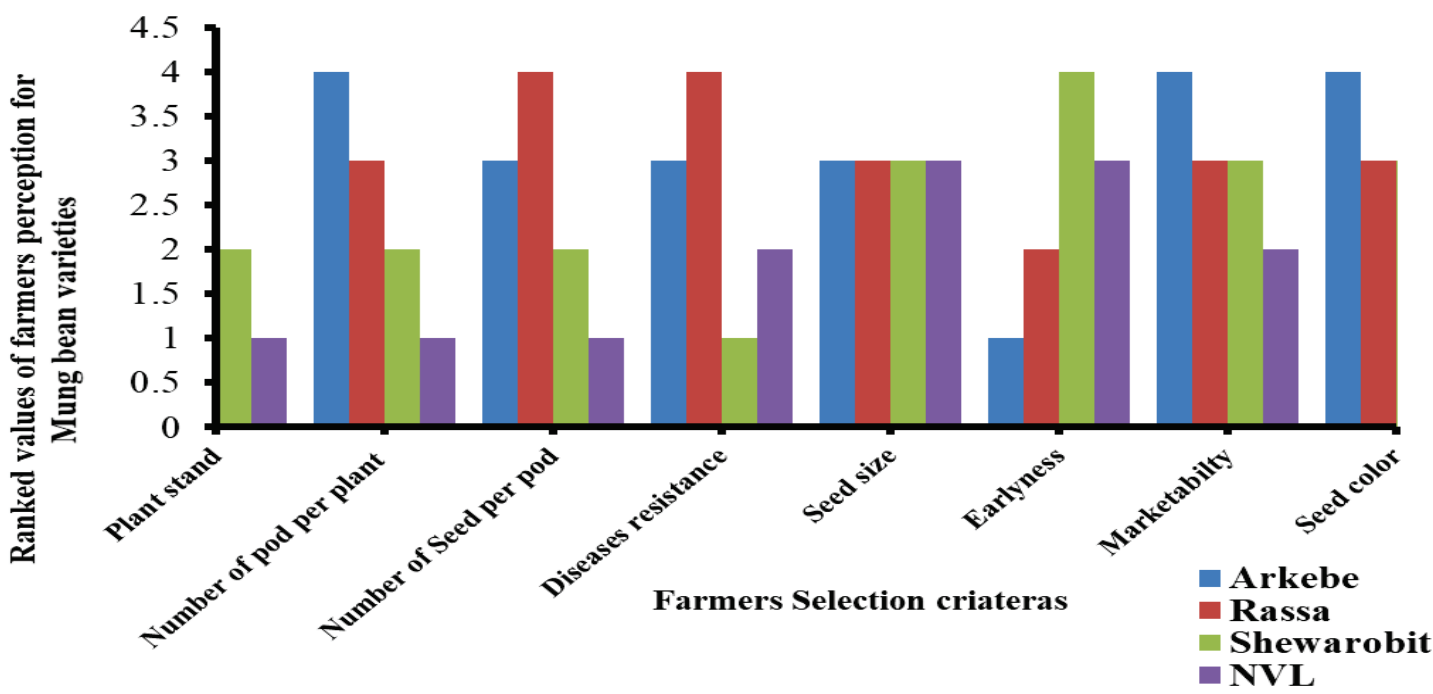

Graph 2 Showed the farmer's Preferences Scored and Ranked value for Mung bean different varieties

Graph 2 indicated that variety Arkebe the preferred by plant stand, number of pod per plant, marketability and by its seed color as compared to other varieties of mung bean. Rassa is the most preferred variety by its number of seed per pod and diseases resistance than others. Shewarobit variety was the earliest variety by its physiological maturity.

Table 4. Pair-wise ranking matrix for selected farmers variety evaluating criteria (mung bean) at Sankura district (Jejebicho research station)

\begin{tabular}{|c|c|c|c|c|c|c|c|c|c|}
\hline $\begin{array}{l}\text { Criteria of } \\
\text { selections }\end{array}$ & NPP & NSP & DR & SS & Er. & Mrk. & SC & $\begin{array}{l}\text { Preference } \\
\text { Rating }\end{array}$ & Rank \\
\hline PS & PS & NPP & NSP & NPP & NSP & NPP & NPP & 1 & 6 \\
\hline NPP & & DR & DR & NSP & DR & NSP & NSP & 4 & 4 \\
\hline NSP & & & Mrk. & DR & SS & NSP & DR & 6 & 2 \\
\hline DR & & & & Mrk. & Mrk. & DR & DR & 8 & 1 \\
\hline SS & & & & & $\mathrm{SC}$ & DR & Mrk. & 1 & 6 \\
\hline Er. & & & & & & Mrk. & $\mathrm{SC}$ & 0 & 8 \\
\hline Mrk. & & & & & & & $\mathrm{SC}$ & 5 & 3 \\
\hline $\mathrm{SC}$ & & & & & & & & 3 & 5 \\
\hline
\end{tabular}

Where, $\mathrm{PS}=\mathrm{Plant}$ stand, $\mathrm{NPP}=$ Number of pod per plant, $\mathrm{NSP}=$ Number of seed per pod, $\mathrm{DR}=\mathrm{Diseases}$ resistance, $\mathrm{SS}=$ Seed Size, Er. $=$ Earliness, Mrk. =Marketability, and $\mathrm{SC}=$ Seed color 
The two way ranking matrix of variety selection criteria was made by farmers to evaluate and to select the most important varieties for better Mung bean grain production. The farmers were so keen to compare the criteria and rank them in order of importance. Accordingly, the selection criteria were ranked by the farmers in the order: disease resistance, number of seed per pod, marketability, number of pod per plant, seed color, plant stand, seed size, and earliness (Table 4). The experimental results of (Wondimkun and Nibret, 2021; Fekadu, 2013; Ceccarelli and Grando 2006) revealed that participatory research is important to understand traits or combinations of traits of interest to farmers, which are in a wider scope than breeders alone. Participatory variety selection (PVS) enables to confirm the chance to well understand the farmers' situation, their preferences and their indigenous knowledge in setting criteria and comparing and prioritizing the without any confusion. Moreover, women headed households. Similar report facilitating adoption by poor farmers in formal plant breeding, and in understanding farmer's preferences (Fekadu, 2013; Maurya et al., 1988; Sperling et al., 1993; Joshi and Witcombe, 1996) variety evaluation and selection had diversified selection criteria to accept and reject mung bean variety (Table 3). This diversity during selection is an indication of the complexity of users' preference. The founding's of (Wondimkun and Nibret, 2021; Abraham et al., 2016; Asrat, 2008) reported that, when there is more diversity in selection criteria, there is better chance of maintaining on farm diversity since positive traits are seldom found on single variety. Disease was the major decisive criteria in retaining and rejecting the variety, number of seed per pod was the second most important criteria for rejection and accepting the varieties of mung bean by farmers. However earliness was ranked the least and it was less important to select varieties.

\section{CONCLUSIONS AND RECOMMENDATION}

Mung bean is originated from India and it has diversified to East, South, Southeast Asia (China) and some countries in Africa. Mung bean is an important pulse crop in Asia because of its high protein content and ability to improve soil fertility. The genus Vigna has been broadened to embrace about 150 species; twenty two species are indigenous to India and sixteen to Southeast Asia, but the principal number of species are originate in Africa. Mung bean is a recent introduction in Ethiopian pulse production and grown in different parts of our country. Mung bean enables to fix atmospheric nitrogen under normal soil fertility condition by mung bean valued $47 \mathrm{~kg}$ $\mathrm{ha}^{-1}$. Its seed contains $22.5 \%$ protein, $9.4 \%$ moisture, $2.05 \%$ fat, $6.95 \%$ fiber and $343.5 \mathrm{kcal} / 100 \mathrm{~g}$ energy. Participatory Variety Selections (PVS) can thus effectively be used to identify farmer's acceptable varieties that are better than old and obsolete varieties with which farmers stick for long period. Participatory varietal selections are farmer-centered varietal selections limited to testing of the finished varieties. Farmers evaluate multiple traits that are important to them and help to increase on farm varietal diversity, faster varietal replacement and rapid scaling up. Moreover, quality traits like milling percentage, cooking and keeping quality, taste, and market price can be assessed in PVS that are difficult or expensive to evaluate in conventional trials. Although Ethiopia has high potential for increasing mung bean productivity and quality, little is known or unknown about the existing mung bean production, productivity and grain quality of the released varieties of mung bean through participatory variety selection to improve yield and quality and to develop alternative cultivars adaptable to the area. Therefore, it is of paramount importance to identify high yielding and best adapted mung bean varieties for the area. Thus, this study was carried out with the objective of selecting mung bean varieties with the participation of farmers at Sankura and Adamitulu Jido Kombolcha districts on selected kebeles. For this experiment four mung bean varieties, like Arkebe, Rassa, Shewarobit and NVL were used. This experiment was conducted at two locations both at research station (FTC) and on farm level for each location. We had been selected three farmer's field and research station, for baby and mother trial respectively from each location. The farmers were invited from each location to select the best variety based on; plant stand, number of pod per plant, number seed per pod, diseases resistance, marketability, seed size and seed color. The overall farmer's selection showed primarily Arkebe and secondly Rasa varieties respectively. Similarly, results of statistical analysis showed as higher grain yield was obtained from both Arkebe and Rasa varieties. Therefore, farmers have to be advised to produce both Arkebe and Rasa as compared to other mung bean varieties around Adamitulu Jido Kombolcha and Sankura districts and other similar agro-ecologies.

\section{ACKNOWLEDGEMENT}

We would like to acknowledge Wondo Genet Agricultural Research Center crop research process for providing all the necessary facilities and support during the entire experimentation. Our acknowledgement also to Mr. Wukyanos Erdachew of field assistance who collect all necessary data from all experimental fields during experimentation time and also we want to acknowledge of Adamitulu Jido Kombolcha and Sankura wereda Agricultural office experts, Kebele Das and farmers by their support, selecting and organization of farmers and providing their land for conducting these research activities'. 


\section{REFERENCES}

Abbas, H. M. and Shah H. U. 2007. Proximate and Mineral Composition of Mung Bean

Adhiena M, Muez M, Mizan T. (2015). Evaluation of mung bean genotypes for seed yield and other yield related traits in low lands of South Tigray, Ethiopia. Journal of Natural Sciences Research 5(13):165-167.

Asim Muhammad, Aslam Muhammad, Hashmi n.i. and Kisana Nafees Sadiq. 2006. Mungbean (Vigna Radiata) In Wheat Based Cropping System: An Option For Resource Conservation Under Rainfed Ecosystem, Pakistan Journal of Biotechnology 37(4): 1197-1204, 2006.

Delfin, E.F.,Erlinda S.P.,Torres,F.G. Santos P.A. 2008. Biomas, nitrogen uptake and fixd nitrogen partitioning in field grown mungbean (Vigna radiata L.Wilczek) inoculated with Bradyrehizobium sp. Philippines Journal of Crop Science (PJCS)

ECX (Ethiopian Commodity Exchange). 2014. "Ethiopian commodity exchange rings bell for Mung Bean, January 23, 2014 Addis Ababa, Ethiopia".

EPP (Ethiopian Pulses Profile),"Ethiopian export promotion agency, product development and market research directorate, May 2004 Addis Ababa, Ethiopia" 2004.

Fantaye Belay, Hintsa Meresa, Shambel Syum and Atsbha Gebresilasie (2019) Evaluation of improved mung bean (Vigna radiata L.) varieties for yield in the moisture stress conditions of Abergelle Areas, Northern Ethiopia Journal of Agricultural Science and Practice 4(4);139-143.

Jibril Temesgen, Taye Kufa and Zeleke Wondimu. 2015. Effect of Plant Density of Hybrid Maize and Common Bean Varieties on the Productivity of Intercropping System at Jimma, South West Ethiopia, Global Journal of life Sciences and Biological Research, 1(1):7-17.

Khan, S., S. Shah, H. Akbar, and S. Khan. 2001. Effect of planting geometry on yield and yieldcomponents in mungbean.Sarhad Journal of Agriculture 17:519-520.

Kapinga, R. E., Jeremiah, S. and Rees, D. (2003). Farmer criteria for selection of sweetpotato varieties, results from Tanzania. In: Rees, D., Van Oirschot, Q. and Kapinga, R. (Eds.), Sweetpotato postharvest Assessment: Experiences from East Africa, Chattam, UK, Natural Resources Institute. pp. 9-21.

Habte U (2018). Evaluation of adaptability of mungbean varieties in moisture stress of Eastern Harerghe Zone. Agricultural Research and Technology 13(2): 555-880

Hayat, R., S. Ali, S. S. Ijaz, T. H. Chatha and Siddique M. T. 2008. Estimation of N2 Fixation of Mung Bean and Mash Bean through Xylem Ureide Technique under Rainfed Conditions. Pak. Journal of biotechnology 40(2): 723-734.

Ibedo, A.S. 2014. Analysis of the greengram value chain in Uganda. (MSc. Thesis). Makerere University,Kampala, Uganda. 113pp.

Mondal, MMA, Puteh AB, Malek MA, Ismail MR, Rafii MY, Latif MA. (2012). Seed yield of mungbean (Vigna radiata (L.) Wilczek) in relation to growth and developmental aspects. the Scientific World Journal Article ID 425168,7

Nair, R.M.,Yang,R.. Easdowna W.J, Thavarajah D., Thavarajah, P.Hughes J.and Keatinge J (2013). Biofortification of mungbean (Vigna radiata) as a whole food to enhance human health, Journal of the Science of Food and Agriculture 93(8)

Polhill R. M. and Maesen vander L. J.G. 1985.'Taxonomy of grain legumes,"Journal of Biological Sciences, 1; 21-27.

Rasul F, Cheema MA, Sattar A, Saleem MF, Wahid MA (2012). Evaluating the performance of three mungbean varieties grown under varying inter-row spacing. Journal of Animal and Plant Sciences 22(4):1030-1035.

Smith Kathleen N, Alexandra Penkner, Kunihiro Ohta, Franz Klein and Alain Nicolas. 2001. B-type cyclins CLB5 and CLB6 control the initiation of recombination and synaptonemal complex formation in yeast meiosis, Elsevier Science Ltd. 11:88-97.

Teame G, Ephrem S, Lemma D, Getachew B (2017). Adaptation study of mungbean (Vigna radiata) varieties in Raya valley, Northern Etiopia. Current Research in Agricultural Sciences 4(4):91-95

Wedajo G (2015). Adaptation study of improved mung bean (Vigna radiata) varieties at Alduba, South Omo, Ethiopia. Research Journal of Agriculture and Environmental Management 4(8):339-342.

Witcombe J.R ., Arun Joshi, Joshi K.D and Sthapit B.R. 1996. Farmer Participatory Crop Improvement. I: Varietal Selection and Breeding Methods and their Impact on Biodiversity, Experimental Agriculture 32(04):445 - 460.

Yehuala Kassa, Daneil Admasu, Abiro Tigabe, Amsalu Abie and Dejene Mamo (2018) participatory on farm evaluation of improved mungbean technologies in the low land areas of north shewa zone amhara region, Ethiopia Journal of Agricultural Extension and Rural Development 10(8); 158-164. 


\section{APPENDICES}

Appendix Table 1. Mean square values of ANOVA on the agronomic and yield components of mung bean participatory variety selection at Jejebicho research station

\begin{tabular}{lllllllllll}
\hline SOV. & DF & PH & BN & NPP & NSP & AGB & DPM & TSW & GY & HI \\
\hline Replication & 3 & 41.42 & 0.18 & 3.39 & 0.56 & 5312.34 & 17.72 & 150.32 & 2.00 & 0.12 \\
Treatment & 3 & $5.10 \mathrm{~ns}$ & $0.29 \mathrm{~ns}$ & $70.72 *$ & $12.81^{*}$ & $11170.43 *$ & $72.19^{*}$ & $458.39 *$ & $11.24^{*}$ & $0.010^{*}$ \\
Error & 9 & 37.00 & 0.33 & 8.52 & 0.68 & 1355.61 & 6.55 & 159.83 & 5.96 & 0.013 \\
\hline CV & & 17.82 & 10.07 & 12.94 & 6.87 & 17.49 & 2.86 & 22.62 & 13.73 & 12.96 \\
\hline
\end{tabular}

Appendix Table 2. Mean square values of ANOVA on the agronomic and yield components of mung bean participatory variety selection at Ziway farmer training center in Abine Germama Kebele FTC'.

\begin{tabular}{|c|c|c|c|c|c|c|c|c|c|c|}
\hline SOV. & $\mathrm{DF}$ & $\mathrm{PH}$ & $\mathrm{BN}$ & NPP & NSP & AGB & DPM & TSW & GY & $\mathrm{HI}$ \\
\hline Replication & 3 & 62.82 & 0.47 & 4.11 & 0.25 & 92596.87 & 7.58 & 62.40 & 0.53 & 1.37 \\
\hline Treatment & 3 & $215.31 *$ & $0.004 \mathrm{~ns}$ & $21.82 \mathrm{~ns}$ & $3.23 *$ & $15670.61 \mathrm{~ns}$ & $14.42 *$ & $246.06^{*}$ & $6.28 *$ & $0.47^{*}$ \\
\hline Error & 9 & 24.36 & 0.25 & 37.92 & 0.20 & 22747.26 & 4.42 & 33.28 & 0.36 & 0.36 \\
\hline $\mathrm{CV}$ & & 10.66 & 8.60 & 18.00 & 4.47 & 30.45 & 2.30 & 9.94 & 10.36 & 10.33 \\
\hline
\end{tabular}

